\title{
Assessing the Elasticities of Electricity Consumption for Rural and Urban Areas in Malaysia: A Non-linear Approach
}

\author{
Hussain Ali Bekhet \\ Department of Finance \& Economics, College of Business Management and Accounting \\ Universiti Tenaga Nasional (UNITEN), Kampus Sultan Haji Ahmad Shah, Pahang, Malaysia \\ Tel: 60-9-455-2020 Ext: 2049 E-mail: profhussain@uniten.edu.my, drbekhet1953@hotmail.com \\ Nor Salwati bt Othman \\ Department of Finance \& Economics, College of Business Management and Accounting \\ Universiti Tenaga Nasional (UNITEN), Kampus Sultan Haji Ahmad Shah, Pahang, Malaysia \\ Tel: 60-9-455-2020 ext: 3399 E-mail: norsalwati@uniten.edu.my
}

\begin{abstract}
This paper investigates and estimates the price and income elasticity of electricity consumption and then compares the level of sensitivity of demand for electricity in the rural and urban areas in Malaysia. The non linear model was employed to estimate the elasticity of electricity consumption. The electricity demand has been estimated as a function of tariff, real GDP, gas price and population in the rural and urban population. The gas price has been used as a proxy to measure the level of sensitivity goods by using the annual data covering the 1980-2009 period. The results showed that the income elasticity $\left(E_{y}\right)$ was less than unity which indicated electricity as a necessity good to the people in Malaysia. The reaction of electricity consumption was found to be greater in the urban area compared to the rural area. The higher sensitivity of electricity consumption in the urban population was due to higher exposure to electricity appliances and facilities.
\end{abstract}

Keywords: Elasticities, Electricity consumption, Rural and urban, Unit root test, Co-integration.

\section{Introduction:}

Since the past three decades, the topic of elasticities has been researched by many researchers (such as Huang, 1993; Hondroyiannis, 2004; Holtedahl, 2004; Bose, 1999; Filippini, 2007; Narayan, 2007). However, the focus of their studies is not similar in term of the location (countries) of the studies, time period and the proxy they employed for endogenous variables. For the above reasons, the outcomes of these studies are predicted to be different especially for a country with different economic background.

The term "elasticities" is most commonly referred to sensitivity or responsiveness. Generally, it was used to quantify the response in one variable when another variable changes (Case and Fair, 2009; Perloff, 2009). Specifically, these elasticities were divided into three sub-criteria namely; price elasticity $\left(E_{p}\right)$, cross elasticity $\left(E_{c}\right)$ and income elasticity $\left(E_{y}\right)$. The price elasticity $\left(E_{p}\right)$ refers to percentage change in one variable, due to the changes in its own price. The cross elasticity $\left(E_{c}\right)$ refers to percentage change in one variable due to the changes in the price of substitute product. Finally, the income elasticity refers to percentage change in one variable due to the change in income (GDP). These elasticities estimates have particular relevance for designing pricing policies (Bose and Shukla, 1999). The effects of any price revisions on consumption will depend on the price elasticity (Filippini, et al, 2004). On the other hand, the information regarding income elasticity is also important especially in the case of a rapidly developing country where one can expect to see large increases in income of households in the next decades (Filippini, et. al, 2004).

The termination of electricity rebate (for consumers having a bill of RM20 and less) on December 31, 2009 serves as a "wake up call" to a researcher to estimate how the electricity consumption changes in response to the changes in electricity tariff. Does the change in electricity tariff give a big impact on the quantity of electricity usage (elastic) or does it give any impact at all (inelastic)? Or is there any variable that could give a greater impact to the quantity of electricity consumption? By knowing how sensitive or responsive electricity consumption is to the electricity tariff changes, we can predict a suitable tariff to be imposed on particular consumers in Malaysia and to suggest a suitable strategy to the policy makers in order to increase the revenues.

In view of the above, an attempt has been made in this paper to estimate the elasticity of electricity consumption in Malaysia and then to compare the level of sensitivity of electricity consumption towards the changes in urban and rural population. This study was focused in these areas to compare their consumption elasticity as it was assumed that electricity consumption in rural and urban area is totally different in terms of the level of exposure to electricity appliances, the distances from power station, population densities, poverty levels and skill availability (Haanyika, 2008). At the same time, this interest is mainly due to the fact that electricity consumption elasticities of population in rural and urban areas are important for assessing the proposal to revise electricity rates and for predicting the 
needs for electricity consumption in future period. An accurate estimation enables the policy makers to promote the efficient use of electricity (Narayan, et al., 2007) and increases the welfare of society.

In order to accomplish the above objectives, we apply the non linear model to estimate the elasticity of electricity consumption. The electricity consumption was a function of electricity tariff, gas price, GDP, urban and rural population. The rest of the paper is structured as follows: Section 2 presents the background of electricity sector in Malaysia. Section 3 discusses literature review. Section 4 defines the data and variables. Section 5 discusses the methodology. Section 6 analyzes the results. Section 7 discusses the policy implication and finally section 8 includes some conclusion and suggestion for further study.

\section{Overview of electricity sector in Malaysia:}

Since the past three decades, the role of electricity sectors is characterized as a vital concern in accelerating Malaysia economics namely as a growth and income redistribution instrument. In the Eight Malaysia Plan, a total of RM463.6 million was spent for the implementation of the rural electrification program, which benefited an additional 101,530 rural households in Malaysia. Of this amount, 30\% benefited the rural household in Sabah, 50\% benefited rural household in Sarawak and the remainder benefited rural household in Peninsular Malaysia. The increase in rural electricity coverage might accelerate the economic development in the rural area and create more job opportunities to the respective communities. Moreover, this development will raise the standard of living in the rural and urban areas and alleviate poverty. Also, the Ninth Malaysia Plan carried the government mission to reduce the disparity of income levels especially between rural and urban areas as well as between rich and poor people. In finalizing the Malaysia $10^{\text {th }}$ plan, the government still emphasizes on eliminating unequal socioeconomics by reducing poverty. Other strategy that links with the previous mission is by imposing a rebate to the consumers having a bill of RM20 and less. By imposing rebate, the respective communities are able to increase their disposable income and allocate more of their income for other purposes such as education and health or it may even increase their standard of living.

Other than income redistribution instrument, electricity sector could also be seen as a growth instrument. Several studies found a positive connection between electricity consumption and economic growth (Yoo, 2006; Tang, 2008; and Chandran, 2010). These studies found that there is a causal flow from electricity consumption to economic growth. Figure 1 shows the growth rate of the electricity consumption and GDP in Malaysia. The total electricity consumption recorded a growth rate of $9.2 \%$ for the period of 1980-2009. There was kWh 9.363 billion of consumption in 1980, increasing to $\mathrm{kWh} 22.35$ billion in 1990, and in 2008 the electricity consumption continuously increased to $\mathrm{kWh} 102.657$ billion. On the other hand, the GDP was recorded at RM100.29 million in 1980, an increase by $6.2 \%$ per year for the $1980-2008$ period. The main reason for the growth of electricity demand was the development of transport sectors such as the railway system, particularly the light rail transit in Klang Valley and inter-city commuter train service and tremendous development of Information Communication Technology (ICT) (National Energy Balance, 2007).

The strong growth in manufacturing activity, supported by increases in export and strong domestic demand, higher tourism activity and the opening of new retail outlet also contributed to growth in electricity consumption (National Energy Balance, 2007). Electricity consumption in Malaysia stands as the second highest among ASEAN members (Tang, 2008). From our visual observation, we found that the electricity consumption and population in rural and urban areas were moving upward over the period of 1980-2009. The growth rate of the total population was reported at $2.5 \%$. [See figure 2]

In order to meet the demands of electricity from various sectors, the government invested huge amounts of money in a mega project such as Bakun Hydroelectric Project. The government invested RM41.1 billion in electricity supply industry ( $8^{\text {th }}$ Malaysia Plan) and this investment was demand-driven with more than one half of it accounted for generation activity [see figure 1]. In order to secure and strengthen the grid system, a total of RM17.6 billion was spent on upgrading and constructing transmission lines as well as improving the distribution network $\left(8^{\text {th }}\right.$ Malaysia Plan).

\section{Past literature review:}

Several studies have been conducted to address various aspects of electricity consumption and factors influencing it. Most of the studies show the existence of relationship between electricity consumption and electricity price (tariff), GDP and population of countries. Al-Ghandoor et al., (2009) studied the fuel and electricity consumption in Jordan. They found that population income and fuel price are the significant factors of electricity consumption and population is a significant factor of fuel consumption. Bianco et al., (2009) investigate and forecast the long run consumption in Italy. They observed that the electricity consumption responds to GDP and GDP per capita changes. Also, the increase in the total electricity consumption is driven by both domestic and non domestic consumptions. Pao (2004) analyzed and forecast Taiwan's electricity consumption by using linear and non linear model. He found that population and national income affect Taiwan's electricity consumption the most, followed by CPI and GDP. The results also showed that non linear model is more appropriate to be applied in Taiwan. 
The overall findings show that the factors affecting electricity consumption may vary from one region to another. The predictor for one region may not be appropriate for another region. Therefore, a different model should be developed in different regions for efficient planning.

Besides studies on factors influencing electricity consumption, the analysis on price and income elasticity of electricity consumption is also a vital concern in the past decade. Previous studies (Hondroyiannis, 2004; Holtedahl, 2004; Bose, 1999; Filippini, 2007; Narayan, 2007) analyzed the roles of elasticities of demand for electricity. The elasticity of electricity consumption makes up for the general impact of electricity price change (or other factors) on electricity consumption (Bose et al., 1999). It measures the percentage change in electricity consumption resulting from the percentage change in factor influencing demand [GDP (income), price of electricity (tariff) and price of substitute or complementary goods]. The previous researches show that the oil, LPG, kerosene is substitute to electricity. These elasticities estimate have been used by numerous researchers around the world to understand demand behavior and also to undertake other activities like forecasting, demand management and policy analysis (Bose, et al., 1999). These analyses are significantly relevant for designing pricing policies of economies.

Huang (1993) examined the electricity-economic growth nexus for China for the 1950-1980 period. He did not test for any causal relationships, but rather examined the correlation among the variables, and found income elasticity of electricity consumption to be greater than unity. A similar study was conducted by Holtedahl and Joutz (2004) for case of Taiwan for the 1955-1996 period. They found the income elasticity of electricity demand to be unity in the long run, while the relative price of electricity (to petroleum products) elasticity was inelastic. Hondroyiannis (2004) examined the demand for residential electricity for Greece for the 1960-1998 period. He found the income elasticity to be greater than unity, while the price response was inelastic in the long run.

Yamaguchi (2007) made a comparison between the periods of 1986-1993 and 1993-2004, and found that income elasticities increased from 1.076 to 1.679 . It showed that the level of sensitivity towards income was increased after 1993, and the price elasticities were below unity before and after 1993. Zachariadis (2007) used annual data for the 1960-2004 period to examine electricity consumption in the residential and service sectors. However, the results showed that long run elasticities of electricity consumption were greater than unity for income and was measured at -0.3 to -0.4 for prices. There were some researchers who found that income elasticity is greater than unity which means that the electricity consumptions in their researched countries were not sensitive to the change in income (Huang, 1993; Holtedahl, 2004; Hondroyiannis, 2004; Yamaguchi, 2007; and Zachariadis, 2007). Meanwhile other group of researchers found that income elasticity was less than unity (See table 1).

Silk and Joutz (1997) examined the short run and long run elasticities in the US residential electricity demand for the 1949-1993 period. They found that in the long run, income and price elasticities were equal to 0.5 and the price elasticities were in the opposite direction. Meanwhile in the short run, the income elasticity was one half of the long run elasticities. The change in electricity consumption due to a change in oil price is equal to 0.059 . It shows that the electricity consumption is not sensitive to the change in its own price, income, as well as price of substitute. Halicioglo (2007) studied the elasticity of electricity demand in Turkey for the 1968-2005 period and found that the income and price elasticity in the long run are greater than income and price elasticity in the short run. It showed that the level of sensitivity has increased in the long run due to population's ability to respond to the policy changes and the changes can be seen in the long run. Generally, it was in line with the theory of elasticity where the short run elasticities are expected to be lower than the long run elasticities.

Kamerschen (2004) studied the demand for residential, industrial and total electricity for the 1973-1998 period in the US, and he estimated that residential price elasticity is between -0.85 to -0.94 , whereas the industrial estimates range between -0.34 to -0.55 . These results showed that demand from residential sector is more sensitive compared to demand from industrial sector. Wasantha (2009) investigated the short run and long run relationship between electricity consumption and factor influencing demand in Sri Langka for the 1960-2007 period. The long run demand elasticities of income, own price and price of substitute (kerosene oil) were estimated to be $0.78,-0.62$ and 0.14 respectively. The short run elasticities for the same variables were estimated to be $0.32,-0.16$ and 0.10 respectively. The results show that increase of income in the long run is likely to significantly increase the demand for electricity while the increase in price of electricity does not effectively reduce electricity consumption.

Lijesen (2007) also examined the price elasticities in the Netherland. Unfortunately, he found that the price elasticity was equal to -0.0043 which is very low compared to the long run and short run price elasticities conducted by other researchers. Nesbakken (1999) studied the price sensitivity of residential energy consumption by using cross section data from the Norwegian consumer expenditure survey for the 1993 - 1995 period. In Norway, $70 \%$ of energy consumption is electricity use. The results show that the energy price sensitivity in residential energy consumption varies from year to year but it is higher for the higher income households than for low income households. In the short run, the income elasticity was 0.01 and $0.15-0.28$ in the long run. In table 1 , we are summarizing the empirical findings of the elasticities for a number of countries around the globe.

Although several studies on elasticity have been conducted in China, Taiwan, US, etc, the findings were not consistent from one country to another. For this reason, there is a real need to understand the elasticities of electricity consumption in Malaysia. In this paper, we attempt to study the elasticities of electricity consumption in Malaysia by exploring the behavior of consumer in urban and rural areas. 


\section{Research data and variables:}

Annual time series data for the 1980-2009 period were utilized in this study. The annual data of electricity consumption $(E C)$ was collected from Energy Information Administration-EIA (www.eia.doe.gov) and Malaysia Energy Centre (MEC). The electricity consumption was measured in billion kilowatts. The annual data for population (Pop) was collected from Department of Statistics Malaysia (DSOM) and were categorized in terms of population in the rural $(R)$ and urban $(U)$ areas, while the data for GDP $(Y)$ were collected from International Monetary Fund (IMF) after they are compared with DSOM. The data of real GDP was from year 2000 and was used as the base year and it was measured in national currency (RM). It was used as a proxy of income.

Data on gas price $(\mathrm{Pg})$ and electricity tariff $(\mathrm{Pe})$ were also collected from DSOM. Since the actual price of electricity and gas were unavailable (same reported by Chandran, et.al, 2010), we used the price index (base year: 2005) as a proxy. There are a number of studies that have used index as a proxy such as Asafu-Adjaye (2000), Masih and Masih (1998) and Hondroyiannis (2002).

The original data are transformed into natural logarithms, which have economics meaning and they are approximated to view growth rate and elasticities. So, the variables $E C, P e, P g, Y, R$ and $U$, were transformed to lec, lpe, lpg, ly, lr and lu respectively.

\section{Methodology:}

The electricity consumption $(E C)$ can be expressed in general as a function of GDP, electricity tariff, gas price and population in the rural and urban areas. The electricity consumption is the dependent variable and the rest are the independent variables which are expected to influence the level of electricity consumption. The function of electricity consumption can be expressed in Equation [1].

$$
E C_{t}=f\left(Y_{t}, P e_{t}, P g_{t}, R_{t}, U_{t}\right)
$$

where $E C, Y, P e, P g, R$ and $U$ represent electricity consumption, GDP, electricity price (tariff), gas price, population in rural areas and population in urban areas respectively. We can represent this function in a mathematical model as shown in Equation [2].

$$
E C_{t}=Y_{t}^{\beta 1} P e_{t}^{-\beta 2} P g_{t}^{\beta 3} R_{t}^{\beta 4} U_{t}^{\beta 5}
$$

To apply this model, we transformed it to be linear as shown in Equation [3].

$$
l e c_{t}=\beta_{0}+\beta_{1} l y_{t}-\beta_{2} l p e_{t}+\beta_{3} l p g_{t}+\beta_{4} l u_{t}+\beta_{5} l r_{t}+e_{t}
$$

where, $\beta_{0}$ is a constant coefficient and $\beta_{1}, \beta_{2}, \beta_{3}, \beta_{4}$ and $\beta_{5}$ are the coefficients estimate. The coefficient $\beta_{1}$ represents income elasticity, $-\beta_{2}$ represents price elasticity, $\beta_{3}$ represents cross elasticity and $\beta_{4}$ and $\beta_{5}$ represents population growth in the rural and urban areas respectively. The Equation [3] provides the information on long run elasticities.

Economics theory suggests that electricity consumption will have an inverse relationship with the price or tariff. Also, there is a direct relationship between electricity consumption and price of substitute product. This relationship can be expressed through the positive and negative coefficient of $\beta_{1}$ and $\beta_{2}$. In this paper we employed gas price as a substitute to electricity.

Analyzing elasticities will involve the process of examining the stationarity of the time series and verifying the order of co-integration by using the Engle-Granger test. In order to conduct the Engle-Granger test, the series of variables is required to be stationary. This is done by testing for unit root test by using ADF and P.P tests at level $I(0)$. If we failed to reject the null hypothesis $\left[H_{0}: Y_{t} \sim I(0)\right]$, we have to proceed with stationarity test at first difference $I(1)$. If once again we failed to reject null hypothesis $\left[H_{0}: Y_{t} \sim I(1)\right]$, we will proceed to test stationarity at second difference. Usually, the macroeconomics data will achieve stationarity at first or second difference. So, the function of stationarity is to avoid spurious regression results.

The co-integration can be captured by analyzing the stationarity of the residual which is estimated by OLS method. If the residual is stationary, this indicates that there is long run equilibrium among variables (Vogelvang, 2005) and all the variables are accepted by macroeconomics theory to analyze the elasticity of electricity consumption. If the variables are not co-integrated at level [failed to reject null hypothesis $H_{0}: e_{t} \sim I(1)$ ] we must test for co integration at first and then second difference until they are co integrated. The decision whether to reject or not is depended on the value of ADF statistic for residual. If this value is smaller than the critical value of ADF value (Vogelvang, 2005), we have to reject the null hypothesis which means that there is no co-integration. This procedure is crucial because the elasticities are valid only if the variables have the same order of integration. ADF or P.P tests for co-integration will be used to investigate the degree of integration.

If the variables are co-integrated $\left[\left(e_{t} \sim I(1)\right]\right.$, we will estimate the short run elasticities by using the Vector Error Correction model (VECM). The VECM will be estimated according to step 2 in Engle and Granger (1987) as shown in Equation [4].

$\Delta l e c_{t}=\alpha_{0}+\sum_{i=1}^{p} \alpha_{1} \Delta l e c_{t-1}+\sum_{i=1}^{p} \alpha_{2} \Delta l P e_{t-1}+\sum_{i=1}^{p} \propto_{3} \Delta l P g_{t-1}+\sum_{i=1}^{p} \propto_{4} \Delta l Y_{t-1}+\sum_{i=1}^{p} \propto_{5} \Delta l u_{t-1}+\sum_{i=1}^{p} \propto_{6} \Delta l r_{t-1}+\propto_{7} e c t_{t-1}+\varepsilon_{t}$ 
In equation [4], the lagged residual variable $e c t_{t-1}$ stems from the long run Equation [3], which is the error correction term in equation [4]. $\propto_{1}, \propto_{2}, \ldots \ldots \propto_{6}$ are the coefficients to indicate the short run elasticities and $\Delta$ denotes a difference operator. The $\propto_{7}$ can be interpreted as the speed of adjustment (Bekhet \& Nora, 2009). It shows the adjustment of dependent variables (in this case, electricity consumption is the dependent variable) in order to achieve long run equilibrium.

\section{Result analysis:}

We use time series model to estimate the electricity consumption elasticity in Malaysia. The analysis involves three steps: First, we have to make sure that all variables followed normal distribution, then all variables must be stationary and finally variables ought to be integrated at the same level (co-integration). Based on the normality analysis, it was found that all variables were nearly following the normal distribution.

\subsection{Stationarity}

The properties of time series data for the 1980-2009 period were analyzed by using ADF and PP tests. A summary of these tests statistics are presented in Table 2. It is crucial to be sure that the time series variables are stationary before analyzed regression analysis to avoid spurious regression result (Studenmund, 2006). In this test, we include intercept because it was more appropriate with economic practice (Vogelvang, 2005). Based on the analysis, we found that all variables are not stationary at level I(0). In order to make them stationary, they were differenced once, and the results showed that electricity consumption, GDP, electricity tariff and gas price are stationary at the first level difference I(1) and significant at 5\% and 10\% level. For the remainder variables (rural and urban population), they are stationary at second difference at $5 \%$ and $10 \%$ significance level. These results are consistent with the notion that most of the macroeconomics variables are non-stationary at level $\mathrm{I}(0)$, but they will become stationary after the first or second difference (Nelson \& Plosser, 1982; Tang, 2008).

\subsection{Co-integration}

To examine the properties of the regression residual, first of all we estimated the coefficient of the variables above by applying the OLS method and make the residual term. Then, we analyzed the unit root test for residual by using ADF test. This two-step procedure is called the Engle-Granger Augmented Dickey-Fuller test for co-integration or EG-ADF test (Stock \& Watson, 2007). Engle and Granger (1987) have shown that if a long run equilibrium exists among series or variables, a linear combination of the non stationary can be stationary in which they are co-integrated (Ho \& Sin, 2007). The result showed that the value of ADF statistic is smaller than ADF critical value at $10 \%$ significant level $(-4.2982<-4.14)$. These results indicated that all variables are co-integrated as shown in equation [5]. Furthermore, the results show that there is a long run equilibrium relationship between the variables above. This indicated that all the variables are accepted by macroeconomics theory to analyze the elasticity of electricity consumption. Since all variables are co-integrated, the elasticities can be explained by computing the coefficients of the Equation [5]. These coefficients will be discussed at the next section.

\subsection{Short run and long run elasticities}

The coefficients in Equation [5] denoted the long run elasticities. The results show that income elasticity for electricity $\left(E_{y}\right)$ is less than unity and consistent with the study by Tang (2009) and Chandran et. al. (2010). These results indicate that electricity consumption is not responsive to the change in income due to the role of electricity as a necessity good to the community. The growth of electricity consumption due to the growth in urban population was found to be greater than unity while the growth of electricity consumption due to the growth in rural population was found to be less than unity. These results indicated that electricity consumption is sensitive to the changes of urban population. These results are consistent with Tang (2009), where he found that electricity consumption was sensitive to the changes in population (but he did not split the population into urban and rural population). However, the reaction towards the changes in rural population was found to be less than unity and was not significant. The greater response from urban population was due to higher exposure to electricity appliances, commuter, habit and other facilities compared to people in the rural area. The result of the price elasticity was found to be insignificant and consistent with earlier result obtained by Chandran (2010). Since the cross elasticity by using gas index as a proxy (from the best of our knowledge) is the first time study in Malaysia, we cannot make a comparison with the previous study and it is also found to be insignificant.

\begin{tabular}{|c|c|c|c|c|c|c|}
\hline $\operatorname{lec}_{t}=$ & -15.17 & $\begin{array}{r}+0.84 l Y_{t} \\
(0.0001)\end{array}$ & $\begin{array}{l}+0.59 l P e_{t} \\
(0.3834)\end{array}$ & $\begin{array}{c}-0.11 l P g_{t} \\
(0.3376)\end{array}$ & $\begin{array}{l}+0.20 l R_{t} \\
(0.4631)\end{array}$ & $\begin{array}{c}+1.08 l U_{t} \\
(0.0006)\end{array}$ \\
\hline & $t=$ & 4.5948 & 0.8880 & -0.9786 & 0.7456 & 3.9358 \\
\hline & $R^{2}=$ & 0.998 & $D W=1.54$ & \multicolumn{2}{|c|}{$F$ test $=33805.51$} & $(0.0000)$ \\
\hline
\end{tabular}

Since there is an evidence of co-integration $\left[\left(e_{t} \sim I(1)\right]\right.$, the short run elasticities is performed using the VECM. The results are presented in Equation [6]. The results showed the existence of long run relationship between electricity consumption and all exogenous variables [See Equation 6]. In addition, we can see that the coefficient for 'ect' is -0.66 and is statistically significant at $5 \%$. In other words, the electricity consumption system had corrected its previous period's disequilibrium for the long term. However, if the changes of electricity consumption were driven directly by this long run equilibrium error, then it was responding to this feedback by $66 \%$ of speed adjustment. 
However the short run elasticities $\left(E_{p}, E_{y}\right.$ and $\left.E_{c}\right)$ were found to be insignificant because the t-statistic for each variable is greater than $10 \%$ critical value. For the income elasticity, the result was consistent with Chandran (2010).

In order to reduce the number of insignificant endogenous variables, we tried to take off the variables with the highest insignificant level and kept the variables with higher significant level. The results were presented in Equation [7]. It showed that the short run income elasticity was equal to 0.41 and it was significant at $10 \%$ level. This result was consistent with the study by Tang (2009) but not consistent with Bekhet \& Nora (2009). The inconsistency was due to different types of energy used as a dependent variable. In this study, we concentrated on electricity while Bekhet \& Nora, (2009) took energy in general.

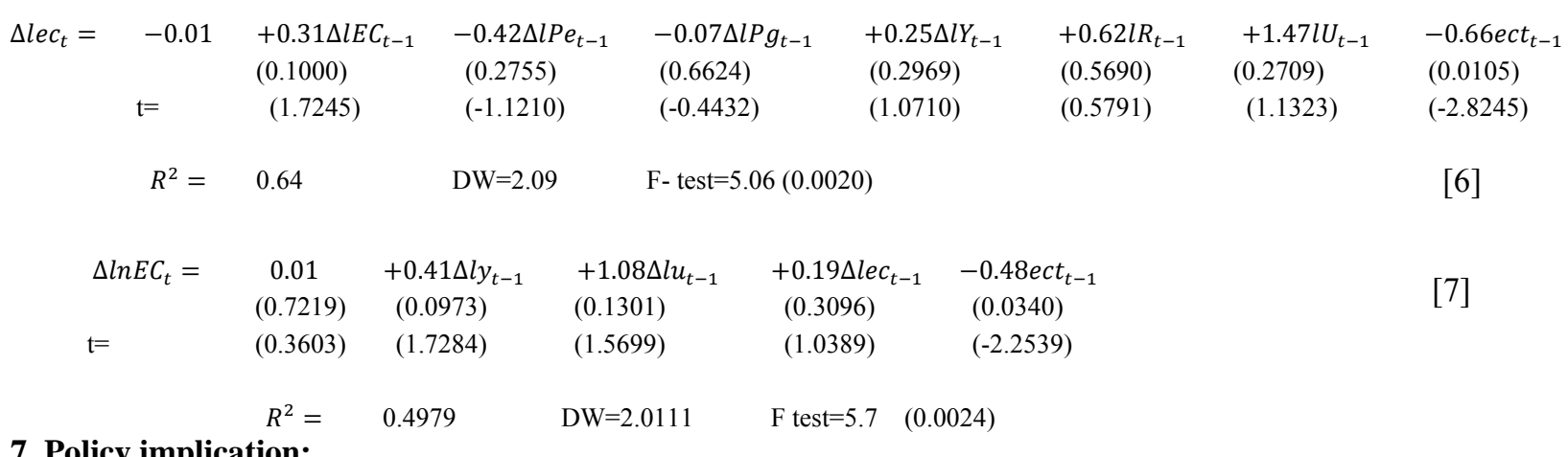

This paper provides the results of electricity consumption elasticities in rural and urban areas. The non linear model was used to determine the responsiveness of electricity consumption to its own price (tariff), GDP and price of substitute product. This study employed the gas price index as a proxy of substitute product. The results showed that the coefficient of $E_{y}$ was found to be less than unity. This indicated that electricity consumption does not drastically reflect the changes in income and proves that electricity is a necessity to the people in Malaysia. They are willing to pay no matter at what cost. In other words electricity has been identified as something they cannot live without. This means that everyday activities need electricity to make things done well. This result is consistent with the results found by other studies (Filipini and Pachauri, 2004; Chandran, 2010; and Tang, 2008).

As a consequence, the strategy to increase or decrease the tariff would not reflect the changes in electricity consumption. In other words, if the policy makers want to aim for energy saving or reduction of electricity consumption, tariff is not an effective tool. But the strategy to increase tariff may put people into depression due to the reduction in their purchasing power. One the other hand, such policy may increase crime and corruption in community. At the same time it would resist Malaysia's objective to move to higher income based economy (BERNAMA, 2009).

On the other hand, government can manipulate this situation in order to increase government revenue. Economics theory showed that the revenue can be increased by increasing the price of goods with inelastic demand. With this strategy government can take advantage from community insensitivity. There would be a conflict between gaining higher revenue and to sustain healthy community development in a country. Also, there would be an opportunity cost between one to another. So at this point, we cannot determine which one is better than other. This study only serves us with an idea about consumer sensitivity towards tariff, income and price of substitute goods. We have to employ other techniques as a complimentary to this study in drafting an effective pricing strategy.

\section{Conclusion and suggestion for further study:}

In this study, we econometrically estimate the electricity consumption elasticities. These elasticities were divided into three sub-criteria namely; electricity price elasticity, cross elasticity and income elasticity. The electricity demand function has been estimated for tariff, GDP per capita, population and gas price. The gas price has been used as a proxy to measure the level of sensitivity goods by using the annual data covering the 1980-2009 period. Income elasticity was found to be less than unity which means people are not sensitive to income change. This result was consistent with Tang (2009) and Chandran (2010). This indicates the role of electricity as a necessity good to the Malaysians. The result for population growth showed that electricity consumption is sensitive to the changes of urban population but not rural population. The results for changes of electricity consumption by the growth of rural population and price elasticity were found to be insignificant. However if we use data in a longer period of time, the results could slightly change and this becomes our study limitation.

This paper provides an idea regarding consumer behavior towards electricity consumption by estimating their reaction or responsiveness to the changes in tariff, income and price of substitute goods. In the Malaysian scenario, we found that electricity consumption is not responsive to the income change. However, this information cannot be categorized as a final source in determining a new pricing strategy. This paper should be extended by exploring the factor driven to higher electricity consumption (such as number of electricity appliances, climatic condition and foreign direct investment as suggested by other researchers) and causal relationship between electricity with other 
macroeconomics variables. With the extended analysis, we believe that it would provide more evidence support to the policy makers in drafting a suitable energy policy in Malaysia's economy.

\section{References}

Asafu-Adjaye J. (2000). The relationship between elasticity consumption, electricity prices and economics growth: Time series evidence from Asian developing countries. Energy Economics, 22, 615-625.

Bekhet, H.A., and Abdullah, A. (2010). Energy Use in Agriculture Sector: Input-Output Analysis, International Business Research, Vol.3, No. 3, pp.111-121.

Bekhet, H.A., and Yusof, N.Y. (2009). Assessing the relationship between oil prices, energy consumption and macroeconomics performance in Malaysia: Co-integration and vector error correction model (VECM) approach, International Business Research, 2, 152-175.

Bianco, V. Manca, O. and Nardini, S. (2009). Electricity consumption forecasting in Italy using linear regression models, Journal of Energy, 34,1413 -1421.

Bose, R.K. and Shukla, M. (1999). Elasticities of electricity demand in India, Energy Policy, 27, 137 - 146.

Chandran, V.G.R Sharma, S. and Madhavan, K. (2010). Electricity consumption-growth nexus: The case of Malaysia, Energy policy, 38, 606-612.

Chen, S-T. Kuo, H.I. and Chen, C. (2007). The relationship between GDP and electricity consumption in 10 Asian countries, Energy policy, 35, 2611-2621.

Filippini, M. and Pachauri, S. (2004). Elasticities of electricity demand in urban Indian household, Energy policy, 32, 429436.

Ghosh, S. (2002). Electricity consumption and economic growth in India, Energy policy, 30, 125-129.

Ho, C-Y. and Siu, K.W. (2007). A dynamic equilibrium of electricity consumption and GDP in Hong Kong: An empirical investigation, Energy policy, 35, 2507-2513.

Hondroyiannis, G. Lolos, S. and Papapetroa, E. (2002). Energy consumption and economic growth: assessing the evidence from Greece, Energy economics, 24, 319 - 336.

Hondroyiannis, G. (2004). Estimating residential demand for electricity in Greece, Energy Economics, 26, 319 334.

Holtedahl, P.A. and Joutz, F. L. (2004). Residential electricity demand in Taiwan, Energy economics, 26, 201 - 224. Halicioglu, F. (2007). Residential electricity demand dynamics in Turkey, Energy economics, 29, 199-210.

Hosoe, N. and Akiyama, S (2009). Regional electric power demand elasticities of Japan's industrial and commercial sectors, Energy policy, 37,4313-4319.

Kamerschan, D.R. and Porter, D.V. (2004). The demand for residential, industrial and total electricity, 1973-1998, Energy economics, 26, 87-100.

Lijesen, M.G. (2007). The real time price elasticity of electricity, Energy economics, 29, 249-258.

Masih, A. M. and Masih, R., Energy consumption, real income and temporal causality: result from a multi study based on co-integration and error correction modeling techniques, 18, 165-183.

Narayan, P.K. Smyth, R. and Prasad, A. (2007). Electricity consumption in G7 countries: A panel cointegration analysis of residential demand elasticities, Energy policy, 35, 4485 - 4494.

Narayan, P.K. Smyth, R. and Prasad, A. (2005). Electricity consumption, employment and real income in Australia evidence from multivariate Granger causality test, Energy policy, 33, 1109-1116.

Nesbakken, R. (1999). Price sensitivity of residential energy consumption in Norway, Energy economics, 21, 495-515.

Ranjan, M. and Jain, V.K. (1999). Modelling of electrical energy consumption in Delhi, Energy, 24, 351 - 361.

Silk, J.I. and Joutz, J.L. (1997). Short and long run elasticities in US residential electricity demand: A co-integration approach, Energy economics, 19, 493-513.

Shiu, A. and Lam, P-L. (2004). Electricity consumption and economic growth in China, Energy policy, 32, 47-54.

Tang, C.F. (2009). Electricity consumption, income, foreign direct investment and population in Malaysia, Journal of economics studies, 36, 371-382.

Tang, C.F. (2008). A re-examination of the relationship between electricity consumption and economic growth in Malaysia, Energy Policy 36, 3077 - 3085.

Wasantha, P.P.A. and Wilson, C. (2009). Estimating short and long term residential demand for electricity: New evidence from Sri Langka, Energy economics.

Wolde-Rufeal, Y. (2006). Electricity consumption and economics growth: A time series experience for 17 African countries, Energy policy, 34, 1106-1114. 
Yoo, S-H. (2005). Electricity consumption and economics growth: Evidence from Korea, Energy Policy, 33, $1627-1632$.

Yoo, S-H. (2005). The causal relationship between electricity consumption and economic growth in the ASEAN countries, Energy Policy, 34, 3573-3582.

Yoo, S-H. (2009). Electricity consumption and economic growth: A cross-country analysis. Energy Policy, 34, 3573-3582.

Yamaguchi, K. (2007). Estimating energy elasticity with structural change in Japan, Energy economics, 29, 1254-1259.

Zachariadis, T. and Pashourtidou, N. (2007). An empirical analysis of electricity consumption in Cyprus, Energy economics, 29, 183-198.

Stock, J.H. and Watson, M.W. (2007). Introduction to econometrics, $2^{\text {nd }}$ Edition, Pearson Addison Wesley. Canada Studenmund, A.H. (2006). Using econometrics: A practical guide, $5^{\text {th }}$ Edition, Pearson International Edition.

Vogelvang, B. (2005). Econometrics: Theory and applications with EViews, $1^{\text {st }}$ Edition, Prentice Hall. U.K

Other references

Star News Paper (1985). "Cut in power rates to stimulate growth" 6 August, Malaysia

Business Times News Paper (1986). "Malaysia has announced cheaper electricity rates for industrial, mining and hotel consumers" 14 March, Malaysia.

Business Times News Paper (1995) 10 May, Malaysia.

Bernama News Paper. (2008). "New electricity tariff structure from July 1" 4 June, Malaysia.

Bernama News Paper. (2009). "TNB reduced power tariff effective March 1" 11 February, Malaysia. 
Table 1. Estimates of the price and income elasticity of electricity consumption.

\begin{tabular}{|c|c|c|c|c|c|}
\hline \multirow{2}{*}{ Country } & \multirow{2}{*}{ Empirical work } & \multirow{2}{*}{ Type of model } & \multirow{2}{*}{ Type of data } & \multicolumn{2}{|l|}{ Elasticities } \\
\hline & & & & Long Term & Short term \\
\hline Greece & $\begin{array}{l}\text { Hondroyiannis, G } \\
(2004)\end{array}$ & $\begin{array}{l}\text { Double log } \\
\text { model }\end{array}$ & $1986-1999$ & $\begin{aligned} E_{Y} & >\text { unity }(1.56) \\
E_{p} & <\text { unity }(-0.41)\end{aligned}$ & $E_{Y}=$ inelastic \\
\hline Taiwan & $\begin{array}{l}\text { Holtedahl, P et al } \\
\text { (2004) }\end{array}$ & $\begin{array}{l}\text { Household } \\
\text { production theory }\end{array}$ & $1955-1996$ & $\begin{array}{l}E_{y}=\text { unity } \\
E_{c}<\text { unity } \\
\text { (to petroleum product) }\end{array}$ & $E_{p}<$ unity (inelastic) \\
\hline India & $\begin{array}{l}\text { Bose, R.K et al } \\
\text { (1999) }\end{array}$ & $\begin{array}{l}\text { Double log } \\
\text { model }\end{array}$ & $\begin{array}{l}\text { 1985/6-1993/4 } \\
\text { (pooling data) }\end{array}$ & $\begin{array}{l}E_{y}>\text { unity } \\
\text { (for commercial and large } \\
\text { industrial sectors) } \\
E_{y}<\text { unity } \\
\text { (for residential and SMI) }\end{array}$ & $\begin{array}{l}E_{p}>\text { unity }(-1.35) \\
\text { (for agriculture sectors) } \\
E_{p}>\text { unity } \\
\text { (for residential, } \\
\text { large industries, } \\
\text { commercial and SMI) }\end{array}$ \\
\hline India & $\begin{array}{l}\text { Filipini, } M \text { et al } \\
\text { (2007) }\end{array}$ & $\begin{array}{l}\text { Double log } \\
\text { model }\end{array}$ & $\begin{array}{l}\text { 1993/1994 } \\
\text { cross section data }\end{array}$ & & $\begin{array}{l}E_{p}<\text { unity } \\
E_{y}<\text { unity } \\
E_{c}<0 \\
\text { (to LPG) }\end{array}$ \\
\hline $\begin{array}{l}\text { G7(Canada, } \\
\text { France, } \\
\text { Germany, } \\
\text { Italy, Japan, } \\
\text { UK and US) }\end{array}$ & $\begin{array}{l}\text { Narayan, P.K et al } \\
(2007)\end{array}$ & $\begin{array}{l}\text { Multivariate } \\
\text { Regression }\end{array}$ & $1978-2003$ & \multicolumn{2}{|c|}{$\begin{array}{l}E_{p}>\text { unity } \\
E_{y}<\text { unity } \\
E_{c}>\text { unity }\end{array}$} \\
\hline China & Huang (1993) & & $1950-1980$ & \multicolumn{2}{|c|}{$E_{y}>$ unity } \\
\hline USA & Silk and Joutz (1997) & $\begin{array}{l}\text { Econometric } \\
\text { and ECM }\end{array}$ & $1949-1993$ & $\begin{array}{l}E_{y}=0.5 \\
E_{p}=0.5\end{array}$ & $\begin{array}{l}E_{y}=0.25 \\
E_{c}=0.059 \\
\text { (to a change in oil price) }\end{array}$ \\
\hline Japan & Yamaguachi (2007) & $\begin{array}{l}\text { Co-integration } \\
\text { model }\end{array}$ & $\begin{array}{l}1986-2004 \\
\text { (structural changed } \\
\text { in 1993) }\end{array}$ & $E_{y}>$ unity & \\
\hline Turkey & Halicioglo (2007) & Semi log model & $1968-2005$ & \multicolumn{2}{|c|}{$\begin{array}{l}E_{y}(\text { in long term })>E_{y}(\text { in short term }) \\
E_{p}(\text { in long term })>E_{p}(\text { in short term })\end{array}$} \\
\hline Cyprus & $\begin{array}{l}\text { Zachariadis, T et. Al } \\
\text { (2007) }\end{array}$ & VECM & $1960-2004$ & $\begin{aligned} E_{y} & >\text { unity } \\
E_{p} & <\text { unity }\end{aligned}$ & \\
\hline USA & $\begin{array}{l}\text { Kamerschen et al } \\
(2004)\end{array}$ & $\begin{array}{l}\text { Flow adjustment } \\
\text { model }\end{array}$ & $1973-1998$ & \multicolumn{2}{|c|}{$\begin{array}{l}E_{p}=-0.85 \text { to }-0.94 \text { (residential sectors) } \\
E_{p}=-0.34 \text { to }-0.55 \text { (industrial sectors) }\end{array}$} \\
\hline Sri Langka & Wasantha et al (2009) & ECM & $1960-2007$ & $\begin{array}{l}E_{y}<\text { unity }(0.78) \\
E_{p}<\text { unity }(-0.62) \\
E_{c}<\text { unity }(0.14) \\
\text { (to kerosene oil) }\end{array}$ & $\begin{array}{l}E_{y}=0.32 \\
E_{p}=-0.16 \\
E_{c}=0.10 \\
\text { (to kerosene oil) }\end{array}$ \\
\hline Netherland & Lijesen (2007) & Log linear method & $\begin{array}{l}2003 \text { (electricity } \\
\text { demand on hour } \\
\text { and hour basis) }\end{array}$ & & $E_{p}=-0.0043$ \\
\hline Norway & Nesbakken (1999) & $\begin{array}{l}\text { Econometrics } \\
\text { model }\end{array}$ & $\begin{array}{l}1993-1995 \\
\text { Cross section data }\end{array}$ & $E_{y}=0.15$ to 0.28 & $E_{y}=0.01$ \\
\hline Malaysia & Chandran (2010) & $\begin{array}{l}\text { Energy demand } \\
\text { function }\end{array}$ & $\begin{array}{l}1971-2003 \\
(\mathrm{ARDL})\end{array}$ & $E_{y}=0.15$ to 0.28 & \\
\hline Italy & Bianco et al (2009) & Linear log model & $1970-2007$ & $E_{p}=-0.09$ to -0.24 & $E_{p}=-0.06$ \\
\hline
\end{tabular}

$*$ Note: $E_{p}=$ price elasticity $; E_{y}=$ income elasticity and $E_{c}=$ cross elasticity $* L P G=$ liquid petroleum gas 
Table 2. The results of the unit root test.

\begin{tabular}{|c|c|c|l|l|}
\hline \multirow{2}{*}{ Variables } & At First difference & \multicolumn{2}{l|}{ At second difference } \\
\cline { 2 - 5 } & ADF & PP & ADF & PP \\
\hline $\ln E C_{t}$ & $-4.1827^{* * *}$ & $-4.1909^{* * *}$ & $-5.9621^{* * *}$ & $-15.5750^{* * *}$ \\
\hline $\ln Y_{t}$ & $-3.6030^{* * *}$ & $-3.6315^{* * *}$ & $-5.9110^{* * *}$ & $-10.9631^{* * *}$ \\
\hline $\ln P e_{t}$ & $-8.4860^{* * *}$ & $-8.7389^{* * *}$ & $-7.7940^{* * *}$ & $-22.0757^{* * *}$ \\
\hline $\ln P g_{t}$ & $-5.6482^{* * *}$ & $-5.5166^{* * *}$ & $-6.8952^{* *}$ & $-13.4046^{* * *}$ \\
\hline $\ln R_{t}$ & -1.6173 & -1.6817 & $-4.8041^{* * *}$ & $-4.8041^{* * *}$ \\
\hline $\ln U_{t}$ & -1.4844 & -1.5719 & $-4.7916^{* * *}$ & $-4.7916^{* * *}$ \\
\hline
\end{tabular}

Notes: $\quad *$ and ${ }^{* *}$ represent the rejection of the null hypothesis of nonstationarity at $5 \%$ and $10 \%$ level of significance, respectively.

Source: Output EViews 6.0.

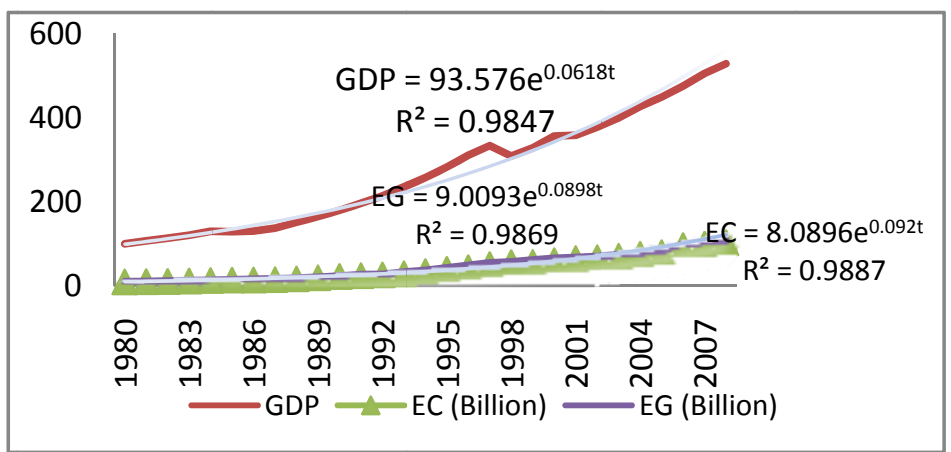

Figure 1. Electricity consumption, electricity generation and GDP of Malaysia (1980-2009)

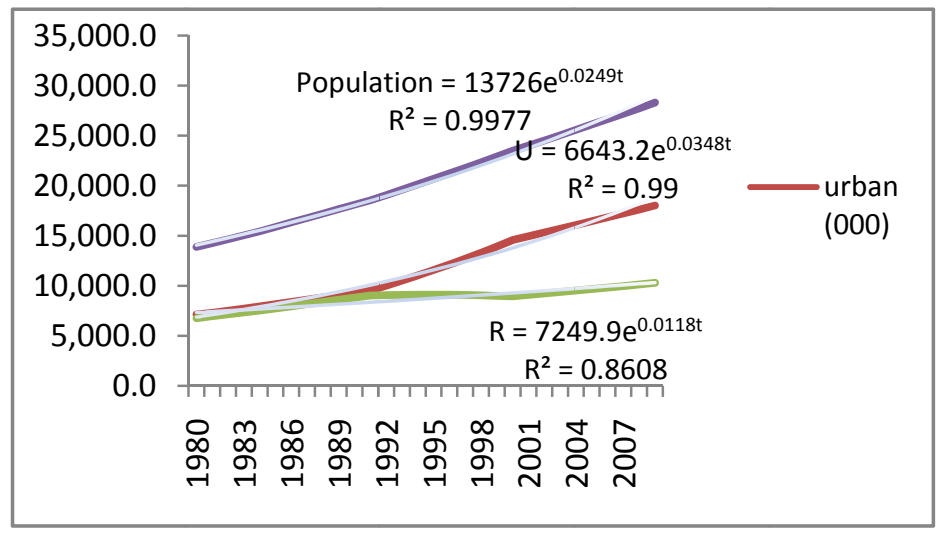

Figure 2. Population of Malaysia 